\title{
PEMIKIRAN PENDIDIKAN KARAKTER IBN MISKAWAIH (TELAAH FILOSOFIS)
}

\author{
Ahmad Ihwani, Muhammad Noupal, Ari Sandi \\ Universitas Islam Negeri Raden Fatah Palembang \\ E-mail: ahmadihwani207@gmail.com, muhammadnoupal_uin@radenfatah.ac.id, arisandi@radenfatah.ac.id \\ How to Cite: \\ Ihwani, A., Noupal, M., \& Sandi, A. (2020). Pemikiran Karakter Ibn Miskawaih (Telaah Filosofis). Fitrah: Journal of Islamic \\ Education, 1(2), 232-247.
}

\section{ARTICLE HISTORY \\ Received :13 December 2020 Revised :30 January 2021 Accepted :30 January 2021 Published :31 January 2021}

\section{KEYWORDS:}

Character Education, Ibn Miskawaih, Philosophical Study

\section{ABSTRACT}

This study aims to analyze the concept of character education according to Ibn Miskawaih in a philosophical perspective with a focus on studies from the side of ontology, epistemology, and axiology. The research method used is the library research method. Sources of literature in this study consist of primary sources and secondary sources. The primary source of literature is the book of tahzib al-Akhlak, and the secondary source is references related to character education such as other books from Ibn Miskawaih's essays, journals, or proceedings. Data analysis begins with unit processing, categorization, and ends with data interpretation. The results showed that ontologically, character education is an effort to curb the three forces that exist in the human soul, so that all body activities become good and spontaneous without the need for prior consideration. Epistemologically, the character education method includes willpower, self-introspection, thariqun thabi'iyyah and opposition methods. Axiologically, character education boils down to the middle path (al-wasath), with main virtues such as al-hikmah (wisdom), al-'iffah (maintaining self-purity), as-Saja'ah (courage) and al'-adalab (justice).

\section{RIWAYAT ARTIKEL \\ Diterima :13 Desember 2020 Direvisi :30 Januari 2021 Disetujui :30 Januari 2021 Diterbitkan:31 Januari 2021}

\section{KATA KUNCI:}

Pendidikan Karakter, Ibn Miskawaih, Telaah Filosofis

\section{ABSTRAK}

Penelitian ini bertujuan untuk menganalisis konsep pendidikan karakter menurut Ibn Miskawaih dalam perspektif filsafat dengan fokus kajian dari sisi ontologi, epistimologi, dan aksiologi. Metode penelitian yang digunakan ialah metode library research. Sumber pustaka pada penelitian ini terdiri dari sumber primer dan sumber sekunder. Sumber pustaka primer yakni kitab tahzib al-Akhlak, dan sumber sekundernya ialah referensi yang berkaitan dengan pendidikan karakter seperti buku lain dari karangan Ibn Miskawaih, jurnal, ataupun prosiding. Analisa data diawali dengan pemrosesan satuan, kategorisasi, dan diakhiri dengan penafsiran data. Hasil penelitian menunjukkan bahwa secara ontologis, pendidikan karakter merupakan upaya menertibkan ketiga daya yang ada pada jiwa manusia, agar seluruh aktivitas tubuh menjadi baik dan spontanitas tanpa perlu, pertimbangan terlebih dahulu. Secara epistemologis, metode pendidikan karakter meliputi kemauan, introspeksi diri, thariqun thabi'iyyah dan metode oposisi. Secara aksiologis, pendidikan karakter bermuara pada jalan tengah (al-wasath), dengan pokok keutamaan seperti al-hikmah (kearifan), al-'iffah (menjaga kesucian diri), as-saja'ah (keberanian) dan al'adalab (keadilan). 


\section{PENDAHULUAN}

Pendidikan karakter sebagaimana diketahui merupakan sebuah agenda yang menjadi perbincangan intelektual pendidikan belakangan ini. Pendidikan karakter sebagai suatu konsep sebenarnya sudah sejak lama ada, hanya saja tidak menggunakan istilah karakter, namun meskipun demikian muatan tentang pembentukan karakter yang baik tetap ada di dalamnya. Seperti misalnya Pendidikan Moral Pancasila (PMP), Pendidikan Pancasila dan Kewarganegaraan, Pendidikan Budi Pekerti, Pendidikan Kewarganegaraan, dan lain sebagainya. (Abong, 2015).

Kemudian konsep pendidikan karakter ini pada tahun 2010, diperkuat dengan dideklarasikannya gerakan nasional pembangunan karakter bangsa atau GNPK oleh Presiden Susilo Bambang Yudhoyono yang mengacu pada lima nilai karakter bangsa supaya dapat menjadi manusia yang unggul, yakni: 1) manusia Indonesia yang bermoral, berakhlak, dan berprilaku baik, 2) mencapai masyarakat yang cerdas dan rasional, 3) manusia Indonesia ke depan menjadi manusia yang inovatif dan terus mengejar kemajuan, 4) memperkuat semangat 'harus bisa" yang terus mencari solusi dalam setiap kesulitan, dan 5) manusia Indonesia haruslah menjadi patriot sejati yang mencintai bangsa, negara, dan tanah airnya. (Kurnia \& Sulfia, 2018).

Perkembangan berikutnya, tepatnya pada tahun 2018 pemerintah dengan berbagai penguatannya, digaungkanlah kembali program ini menjadi sebuah gerakan nasional yang disebut dengan penguatan pendidikan karakter (PPK) yang tertuang dalam Permendikbud nomor 20 tahun 2018. (Lubis, 2019). Ada 5 nilai utama yang perlu dikembangkan sebagai prioritas dalam Gerakan PPK ini, yaitu: 1) Religius, 2) Nasionalis, 3) Mandiri, 4) Gotong Royong, dan 5) Integritas. sesungguhya kelima hal ini adalah nilai utama karakter bangsa Indonesia. (Lubis, 2019).

Adapun sumber yang digunakan dalam penerapan pendidikan karakter ini adalah: 1) Agama, 2) Pancasila, 3) Budaya, 4) Tujuan Pendidikan Nasional, dan 5) UU RI No. 17 tahun 2007. Selanjutnya, nilai-nilai pendidikan karakter yang bersumber dari beberapa hal tersebut meliputi 18 karakter. 1) Religius, 2) Jujur, 3) Toleransi, 4) Disiplin, 5) Kerja Keras, 6) Kreatif, 7) Mandiri, 8) Demokratis, 9) Rasa Ingin Tahu, 10) Semangat Kebangsaan, 11) Cinta Tanah Air, 12) Menghargai Prestasi, 13) Bersahabat/ Komunikatif, 14) Cinta Damai, 15) Gemar membaca, 16) Peduli Lingkungan, 17) Peduli Sosial, dan 18) Tanggung Jawab. (Subekti \& Sumarlam, 2017).

Perspektif Islam menjadikan karakter sebagai tolak ukur ketinggian ilmu dan keshalihan seseorang. Semakin baik karakter yang ditampilkan maka semakin baik pula keislamannya, begitu juga dengan sebaliknya. Karakter dalam Islam tertuang pada Al-Qur'an dan Hadis, sehingga orang yang memiliki karakter menginternalisasikan Qur'an dalam keseharianya.

Namun kondisi saat ini sangat jauh dari apa yang telah dikonsepkan tersebut, melihat situasi sekarang ini maka pendidikan karakter perlu dipertanyakan. Sebagaiamana diketahui bahwa, tingkah laku sebagai ciri dari karakter peserta didik semakin 
mengalami degradasi. Sebagaimana Fatchul Mu'in berpendapat bahwa peserta didik saat ini identik dengan tindakan tawuran, korban budaya cinta-cintaan bahkan sampai kepada seks bebas, dan lain sebagainya. (Mu'in, 2016). Senada dengan hal itu, Ayu Lestari mangatakan bahwa akhir-akhir ini banyak sekali kasus-kasus yang berkaitan dengan hal tersebut, berawal dari banyaknya peserta didik yang mengakses situs-situs porno sehingga kemudian peserta didik tersebut melakukan seks bebas (Lestari, 2017).

KPAI mencatat dalam kurun waktu 9 tahun yakni dari 2011 sampai 2019 ada 37.381 pengaduan kekerasan yang terjadi di sekolah, dan sejumlah kasus pula sudah mewarnai catatan kelam dunia pendidikan di awal tahun 2020. (KPAI, 2020). Lebih lanjut Retno sebagai komisioner KPAI bidang pendidikan menerangkan bahwa ada bermacam-macam kasus dalam hal ini, seperti di tahun 2019 ada 24 kasus dan tercatat di dalamnya 17 kasus yang terkait kekerasan, rinciannya sebagai yaitu 6 kasus kekerasan fisik, 8 kekerasan psikis, 3 kekerasan seksual, 1 tawuran pelajar, 5 korban kebijakan, dan 1 kasus eksploitasi. (Listyanti, 2019).

Meskipun pendidikan karakter bukanlah satu-satunya yang bertanggung jawab akan hal ini, namun pendidikan karakter yang ada di sekolah sebagai sebuah lingkungan yang dominan mempengaruhi peserta didik, paling tidak mampu meminimalisasi perilaku buruk tersebut bahkan mampu mencipatakan peserta didik yang berkarakter sebagaimana yang sudah di harapkan. Oleh karena disorientasi inilah banyak intelektual yang kontra dengan pendidikan karakter ini, begitu banyak hambatan yang menganggu dalam tataran pelaksanaannya. Sebagaimana menurut Munawar Noor banyak sekali dijumpai dalam pelaksanaan pendidikan karakter ini hal-hal yang sangat tidak mendorong tercapainya tujuan pendidikan karakter, seperti transfer of knowledge dalam proses pembelajarannya yang dibuktikan dengan model ujiannya yang terlalu berorientasi pada intelektual peserta didik semata. (Noor, 2018). Kemudian Tabah Subekti dan Sumarlan, yang dalam penelitiannya berkesimpulan bahwa dalam buku teks beberapa pelajaran minim sekali memuat tentang pendidikan karakter, dan meskipun ada itupun didominasi aspek pengetahuan saja, belum sampai pada aspek internalisasi dan implementasi. (Subekti \& Sumarlam, 2017). sisi lain, Masruroh Lubis mengatakan bahwa pendidikan karakter sebenarnya adalah adaptasi dari pendidikan Barat yang tentu tidak semuanya dapat diterapkan di Indonesia terlebih lagi diterapkan di kalangan peserta didik yang muslim. (Lubis, 2019).

Karena perlu dicermati bahwa nilai-nilai pendidikan karakter sebagaimana diuraikan sebelumnya meskipun terlihat sangat baik dan sesuai dengan kemaslahatan bersama, akan tetapi tidak sepenuhnya bisa diterima oleh Islam dan masih harus dipertanyakan lebih mendalam. Seperti "Jujur", dalam Islam tak selamanya kita harus jujur kepada siapa saja. Ada porsi dan posisi serta kondisi yang harus dipertimbangkan. Sebagai contoh, ketika perang dan tertangkap menjadi tawanan. Maka ia sebagai seorang muslim tidak boleh jujur mengatakan dimana letak kelemahan kaum muslim walaupun harus mempertaruhkan 
nyawanya demi agamanya. Dan pada saat itu ia termasuk muslim yang berakhlak mulia. Selanjutnya "toleransi” yang bagaimanakah yang akan ditanamkan kepada seluruh peserta didik dan generasi muda ini? karena dalam Islam toleransi tidak bebas sebebasbebasnya, punya batasan apalagi jika sudah bersinggungan dengan akidah. (Rifai, 2016). Akan ada ketentuan-ketentuan lain yang harus diperhatikan.

Pada kesempatan inilah Islam sebagai agama seharusnya memiliki peran sentral di dalam pendidikan karakter yang hendak dilaksanakan. Namun ada Anggapan yang mengatakan bahwa agama tidak dapat dipakai sebagai pedoman pengatur dalam kehidupan bersama dalam sebuah masyarakat yang plural. Di antaranya Doni Koesoema yang beranggapan bahwa di zaman modern yang sangat multikultural ini, nilai-nilai agama tetap penting dipertahankan, namun tidak dapat dipakai sebagai dasar kokoh bagi kehidupan bersama dalam masyarakat. Lebih lanjut ia mengatakan bahwa, jika nilai agama ini tetap dipaksakan dalam konteks masyarakat yang plural, yang terjadi adalah penindasan oleh kultur yang kuat pada mereka yang lemah. Ungkapan semacam ini adalah pandangan sekuleristik, yang tentunya tidak dapat diterima. (Purnamansyah, 2014). Ringkasnya agama tidak terpisah kan dalam kehidupan manusia, ia hadir sebagai pedoman bagi kehidupan manusia.

Berkenaan dengan di atas dalam perspektif Islam, secara filosofis pendidikan karakter yang berarti mendidik karakter juga mempunyai arti mendidik jiwa. Karena karakter sejatinya adalah hasil dari jiwa. (Prasetiya, 2018) Sebagaimana Carl
Gustav Jung yang dikutip oleh Jalaluddin mengatakan bahwa pada hakikatnya karakter merupakan wujud pernyataan kejiwaan yang ditampilkan seseorang dalam kehidupannya. (Nuriman \& Emzir, 2018)

Karena sebenarnya, badan hanyalah sebagai kumpulan pelbagai entitas material yang membentuk suatu makhluk saja. (Bakri, 2018). Sehingga dalam hal ini, sebagaimana Munawar Noor, pendidikan karakter seharusnya lebih diarahkan kepada aspek rohani dan bukan intelektual semata. Lebih lanjut ia mengatakan bahwa, dengan baiknya aspek rohani maka baik pula aspek lahiriahnya. (Noor, 2018).

Konsep di atas tentu sama sekali tidak akan di dapat jika pendidikan karakternya diadaptasi dari Barat. Karena secara garis besar peradaban Barat berpangku pada sesuatu yang hanya dapat disaksikan dan dirasakan indra serta dapat disahkan dengan metode empiris. Selain daripada itu maka akan ditolak. Dan jiwa bukanlah persoalan yang dapat diselesaikan dengan metode empiris. Oleh karena beberapa alasan inilah, maka pendidikan karakter sebagaimana diketahui sangat perlu untuk direkonstruksi secara epistemologi berdasarkan perspektif Islam.

Menarik apa yang dikonsepsikan oleh Ibn Miskawaih, bahwasanya pendidikan karakter adalah pendidikan yang akan menjadikan peserta didik sempurna. Lebih lanjut Ibn Miskawaih menyatakan bahwa dengan pendidikan karakter maka peserta didik diharapkan mempunyai suatu dorongan untuk selalu melakukan kebaikan yang pada akhirnya akan membawanya pada kebahagiaan. Namun terlebih dahulu, peserta 
didik harus mampu memahami jiwanya. (AlMiskawaih, 2014). Karena menurutnya jiwa adalah pembimbing badan, atau dengan kata lain jiwa akan membetulkan kesalahankesalahan persepsi yang dibuat oleh indra, termasuklah dalam hal ini adalah perbuatan buruk yang hendak dilakukan. (Bakri, 2017). Ibn Miskawaih sangat percaya bahwa pendidikan karakter tidak ada artinya jika tidak memahami seluk beluk jiwa terlebih dahulu. (Hamim, 2017). Hal ini tidak berlebihan, mengingat Ibn Miskawaih memang salah seorang cendikiawan muslim yang fokus menelaah di bidang akhlak, sebagaimana Syarif menyebutnya sebagai the first muslim moralist, yang tentunya mempunyai landasan dalam argumennya tentang pembentukan akhlak. (Zaimudin, 2018)

Sebagaimana diketahui bahwa, Ibn Miskawaih telah menjelaskan tentang bagaimana mendidik dan menanamkan akhlak yang baik pada manusia, dan ia pun meyakini bahwa untuk melakukan kesemua itu tidaklah sesulit yang dibayangkan, asalkan dengan suatu perekayasaan dan pendidikan yang sistematis. (Al-Miskawaih, 2014). Karena dalam perspektif Ibn Miskawaih, karakter manusia dapat diubah meskipun lambat, karena menurutnya karakter itu tidak alami sebagaimana silogisme yang ia paparkan dalam kitab Tahdzib al-Akhlak dengan premis pertama adalah setiap karakter itu dapat berubah dan premis kedua adalah apapun yang berubah itu tidak alami, dengan konklusi adalah karakter itu tidak alami. perubahan karakter itu hanya dapat dilakukan melalui pendidikan yang disiplin dan juga melalui nasehat-nasehat. (Arifin, 2011). Hal ini pun tidak perlu diragukan lagi, Ibn Miskawaih dalam kitab tersebut memberikan contoh adalah dirinya sendiri yang mana ia berkarakter kurang baik menjadi baik dengan pendidikan dan pembiasaan.

Kemudian banyak yang berpendapat bahwa Ibn Miskawaih adalah tokoh yang berhasil mengkombinasikan dengan baik pemikiranYunanidenganal-Qur'andanHadit (Safri, 2017), yang mengindikasikan bahwa pendidikannya tidak bersifat indoktrinasi dan keimanan semata namun lebih bersifat rasional. Seperti misalnya tentang konsep "jalan tengah" yang merupakan pokok kebaikan. Yang mana ia berlandaskan ajaran Islam namun penjabarannya ia lebih menggunakan falsafah etikanya Aristoteles yang termuat dalam Nichomacean Ethics.

Berkenaan dengan hal-hal yang telah disebutkan di atas maka penulis tertarik untuk meneliti konsep pendidikan karakter Ibn Miskawaih dari perspektif filsafat. Perlu diketahui jika diteusuri memang terdapat penelitian yang berkaitan dengan penelian ini seperti tulisan Mulia yang fokus pada pemaparan konsep pendidikan karakter yang ditinjaudaripotensiyangdimilikiolehmanusia itu sendiri. (Mulia, 2019). Tulisan kurniawan yang fokus pemaparan pendidikan karakter dalam konsep Al-Ghazali. (Kurniawan, 2017), tulisan Nalva yang fokus pada konsep midle way pada pendidikan karakter. (Nalva, 2020). Kemudian tulisan rahayu yang fokus pada pendidikan karakternya dengan memperkuat agama, budaya, dan kebijakan pemerintah. (Rahayu, 2019). Tulisan Mubin yang fokusnya pada penerapannya pada masa pandemi. (Mubin, 2020). Tulisan Nurkhalisyah yang fokus pembahasan 
karakternya pada perbandingan pemikiran Ki Hajar Dewantara dengan Ibn Miskawaih. (Nurkhalisyah et al., 2020). Teakhir tulisan Bakri yang membahas karakter dengan cara dari perspektif filsafat manusia. (Bakri, 2018). Berdasarkan kajian-kajian tersebut terdapat ruang kosong pembahasan yang menjadi kekhasan dalam penelitian ini yakni pengkhususan pembahasannya pada tiga aspek filsafat ontologi, epistemologi, dan aksiologi. Sebab banyak penelitian pendidikan karakter pada filsafat hanya parsial pada pemikiran tertentu. Tetapi sangat jarang yang kompleks mencakup aspek ontology, epistemologi dan aksilogi.

Novelty dalam penelitian ini tentu saja ialah menghasilkan pemikiran yang kompleks (secara ontology, epistemologi, dan aksiologi) dari pemikiran Ibn Miskawaih tentang pendidikan karakter. Tentu ini sangat urgen mengingat pembahasan yang ada selalu parsial, sehingga dapat menjadi instrumen pemikiran yang utuh dalam mengembangkan pendidikan karakter di lembaga pendidikan.

\section{KAJIAN TEORI}

Untuk mengetahui pendidikan karakter secara mendasar dan menyeluruh, maka perlu diperhatikan landasan penelaahan ilmu, yang dalam hal ini adalah pendidikan karakter itu sendiri. Dalam disiplin filsafat ilmu, masalah pengetahuan berkisar pada tiga hal, yaitu apa pengetahuan yang menyangkut aspek ontologi, bagaimana mengetahui berkenaan dengan aspek epistemologi, dan untuk apa pengetahuan itu yang berkenaan dengan aspek aksiologi. (Adib, 2013). Dengan demikian, penulis akan menguraikan ketiga hal tersebut sebagai alat untuk meninjau pada pendidikan karakter yang menjadi permasalahan dalam penelitian ini.

Pertama, ontologi dapat dimaknai sebagai teori tentang keberadaan atau dapat juga dimaknai dengan ilmu tentang yang ada. Dalam hal ini, ontologi mengkaji sesuai yang ada, sepanjang sesuatu itu ada. (Ludwig, 2016). Sebagaimana Clauberg yang menyebut ontologi sebagai "ilmu pertama" yaitu studi tentang yang ada sejauh hal itu ada. lebih lanjut ia menyatakan bahwa studi ini dianggap berlaku untuk semua entitas. (Rawnsley, 1998).

Ontologi bersinonim dengan metafisika, yaitu studi filosofis untuk menentukan sifat nyata yang asli (real nature) dari suatu benda untuk menentukan arti, struktur, dan prinsip benda tersebut. Namun di abad ke-17, ontologi disepakati sebagai cabang dari metafisika yang hanya berfokus pada apa yang sudah ada, yakni hakikat atau eksistensi. (Chatterjee, 2011).

Sejarah mencatat bahwa ontologi merupakan salah satu kajian filsafat yang paling kuno. Kajian tersebut membahas keberadaan sesuatu yang bersifat konkret. Beberapa tokoh seperti Thales, Plato, dan Aristoteles merupakan filosouf Yunani yang memiliki pandangan bersifat ontologi. Thales misalnya, melalui perenungannya terhadap air yang ada di mana-mana, ia sampai pada kesimpulan bahwa air merupakan "substansi terdalam" yang merupakan asal mula dari segala sesuatu. (Khojir, 2011).

Sebagai contoh, apa yang menjadi hakikat dari lantai? Secara umum maka 
akan didapati jawaban biasa yang terlihat seperti realitas, seperti rata, padat dan halus, mempunyai berbagai macam warna, terbuat dari bahan-bahan teretntu seperti kayu, keramik, dan lain sebagainya. Jawaban yang demikian bukanlah sebuah hakikat meskipun realitasnya seperti itu. Akan terdapat perbedaan yang mendasar dalam hal ini, tergantung dari sudut pandang yang digunakan. Andaikata seorang ahli fisika di tanya hal seperti itu, maka ia akan menjawab bahwa lantai sesungguhnya adalah "alaspanas" dari gerak molekuler yang mana ia lebih berupa ruang daripada zat. Andaikata ahli kimia, maka lantai tersebut adalah himpunan karbon yang menyatu dalam suatu cara tertentu dan tunduk pada pola tertentu dari pengaruh-pengaruh lingkungan, semisal panas, dingin, lembam, kering, dan oksidasi. (Hayden, 2012).

Berdasarkan uraian tersebut, maka dalam tinjauan ini yang akan dibahas dari pendidikan karakter adalah persoalan hakikat pendidikan karakter sebagai realitas dari pendidikan karakter itu sendiri.

Kedua, Epistemologi bermakna mengkaji mengenai apa sesungguhnya ilmu, dari mana sumber ilmu, serta bagaimana proses terjadinya. Dengan kata lain, kajian tentang epistemologi sangat erat kaitannya dengan bagaimana cara memperoleh ilmu pengetahuan, mengolah, menganalisis, dan membentuk suatu teori, postulat, dan pradigma pengetahuan tertentu. (Thomson, 1964). Dengan sederhana Burhanudian salam mengartikan Epistemologi ini dengan segenap proses yang mendalam untuk memperoleh pengetahuan. (Agung, 2018).

Namun meskipun demikian, dari beberapa rujukan tetap didapati penjelasan yang berbeda dari pemahaman kata epistemologi ini meskipun pada dasarnya adalah sama. Berikut beberapa definisi epistemologi yang diberikan oleh beberapa sumber.

Epistemologi adalah cabang ilmu filsafat yang fokus pada masalah-masalah filosofikal yang mengitari teori ilmu pengetahuan. Ia juga diartikan sebagai cara bagaimana mendapatkan pengetahuan, sumber-sumber pengetahuan, ruang lingkup pengetahuan. (Mudlofir, 2016). Berdasarkan uraian tersebut, maka dalam tinjauan ini yang akan dibahas dari pendidikan karakter ialah cara atau metode pembentukan akhlak pada diri manusia.

Ketiga, aksiologi bermakna nilai-nilai sebagai tolak ukur kebenaran sedangkan etika dan moral sebagai dasar normatif penelitian dan penggalian, serta penerapan ilmunya. Memperbincangkan aksiologi tentu membahas dan membedah masalah nilai. Hubungan antara nilai dan pendidikan sangat erat. Nilai dilibatkan dalam setiap pendidikan baik dalam memilih maupun dalam memutuskan setiap hal untuk kebutuhan belajar.

Menurut Hill, ia mengatakan hakikat pendidikan nilai adalah mengantar peserta didik mengenali, mengembangkan, dan menerapkan nilai-nilai, moral dan keyakinan agama untuk memasuki kehidupan budaya zamannya. Lebih jelasnya Hill ingin menandaskan bahwa pendidikan nilai harus mampu membuat peserta didik menguasai pengetahuan yang berakar pada nilai-nilai tradisionalnya yang mampu menolong menghadapi nilai-nilai modern, berempati 
dengan persepsi dan perasaan orangorang yang tradisional, mengembangan keterampilan kritis dan menghargai nilainilai tersebut, mengembangkan diri sehingga berketrampilan dalam membuat keputusan dan berdialog dengan orang lain, dan akhirnya mampu mendorong peserta didik untuk berkomitmen pada masyrakat dan warganya.

Dengan demikian, setelah diuraikannya tentang aksiologi bahkan dikaitkan dengan pendidikan maka dapat diketahui bahwa dalam pendidikan karakter, aksiologi yang dimaskud adalah menguji dan mengintegrasikan nilai tersebut dalam kehidupan manusia dan meninternalisasikannya dalam kepribadian peserta didik. Pendidikan harus memberikan pemahaman baik, benar, bagus, buruk dan sejenisnya kepada peserta didik secara komprehensif, dalam arti dilihat dari segi etika, estetika, dan nilai sosial. Dalam masyarakat, nilai-nilai itu terintegrasi dan saling berinteraksi. Nilai-nilai di dalam rumah tangga/keluarga, tetangga, kota, negara adalah nilai-nilai yang tak mungkin diabaikan, melainkan sebaliknya harus mendapat perhatian.

\section{METODE PENELITIAN}

Penelitian ini menggunakan metode penelitian library research (risetkepustakaan), dan teknik pengumpulan datanya melalui dokumentasi. Kegiatan dokumentasi dalam hal ini maksudnya serangkaian mencari dan mengumpulkan berbagai data berupa catatan, buku-buku, kitab-kitab, naskah-naskah, dan lain sebagainya yang berhubungan dengan permasalahan yang diteliti dengan cara mengumpulkan berbagai informasi dan data.

Penyajian artikel dengan cara memaparkan dan menganalisis beberapa pendapat, teori dan pandangan Islam yang berkaitan dengan keseluruhan pemikiran Ibn Miskawaih tentang Pendidikan Karakter di dalam Tahzib al-Akhlak wa Tathhir al-A'raq dan data pendukungnya terdiri dari literatur yang berkaitan dengan tema penelitian, baik itu berupa artikel, jurnal, buku, dan sebagainya.

Teknik analisis data yang digunakan memakai pola analisis isi (conten analysis) secara deskriptif dan analitik terhadap sumber utama yaitu kitab Tahdzib alAkhlak wa Tathhir al-A'raq dan juga terhadap data pendukung. Kemudian data tersebut dianalisis pada tipologi satuan sebelumnya disusun berdasarkan tema-tema. Kemudian, dilakukan kategorisasi guna untuk mengelompokkan dan melakukan pemilahan. Dan terakhir adalah penafsiran data dengan menggunakan modus hermeneutik. (Moloeng, 2018). Modus ini digunakan tidak lain adalah untuk membuat jelas dan membuat sesuatu teks yang dalam hal ini pernyataan-pernyataan Ibn Miskawaih yang sifatnya masih kabur/tidak jelas, atau bisa juga bertentangan antara satu pernyataan dan pernyataan lainnya. Sehingga pada akhirnya, tafsiran-tafsiran data tersebut dijadikan sebagai langkah dalam mengambil kesimpulan sebagai jawaban dari rumusan masalah seperti yang telah di jelaskan.

\section{HASIL DAN PEMBAHASAN PENELITIAN}

Sebagaimana yang telah dikemukakan sebelumnya hasil penelitian akan disajikan berdasarkan tiga aspek dalam kajian filsafat 
yakni tinjauan ontologi, epistemologi, dan aksiologi. Sebagaimana berikut:

\section{Tinjauan Ontologi}

Ibn Miskawaih menuturkan sebagai berikut:

$$
\text { كاذل خلق يمكن تغيره ولاشئ مما يمكن تغيره هو بالطبع }
$$

Apapun yang bisa berubah, itu tidak alami. Kalau begitu tidak ada karakter yang alami (Al-Miskawaih, 2014).

Barangkat dari teks ini, Ibn Miskawaih beranggapan bahwa karakter dapat berubah cepat atau lambat melalui disiplin serta nasehat-nasehat yang mulia. Pada mulanya, keadaan ini terjadi karena dipertimbangkan dan dipikirkan, namun kemudian melalui praktik terus menerus akan menjadi kebiasaan. Oleh sebab inilah maka pendidikan karakter adalah hal yang sangat memungkinkan.

Namun meskipun demikian, Ibn Miskawaih pun menyadari akan susahnya untuk menghindar dari kesalahan dan kekurangan serta tidak mampunya manusia mengontrol daya-daya jiwa yang merupakan sumber prilaku manusia ini. Oleh karena itu, Ibn Miskawaih menyadari akan perluya pendidikan yang dalam hal ini berupa nasehat-nasehat dan ketaatan yang baik.

Dengan demikian maka dapat diasumsikan bahwa pendidikan karakter menurut Ibn Miskawaih pada hakikatnya adalah segenap proses untuk membentuk karakter yang baik atau memperbaiki karakter yang buruk dan mengandaikan terciptanya manusia yang sempurna dengan menertibkan ketiga daya yang menjadi sumber prilaku manusia. (Al-Miskawaih, 2014)
Dengan adanya pengertian yang demikian, maka menurut Ibn Miskawaih setidaknya ada tiga tujuan dari pendidikan karakter ini. Pertama, sebagaimana diketahui bahwa pendidikan karakter adalah untuk menciptakan tingkah laku manusia yang baik, sehingga manusia itu dapat berperilaku terpuji dan sempurna sesuai dengan hakikatnya sebagai manusia. Dalam hal ini, diharapkan akan terwujudnya sikap batin yang mampu mendorong secara spontan dan tanpa pertimbangan guna untuk melahirkan semua perbuatan yang bernilai baik. Kedua, untuk mengangkat manusia dari derajat yang paling tercela, derajat yang dikutuk oleh Allah Ta'ala. (Al-Miskawaih, 2014).

Dalam hal ini, erat sekali kaitannya dengan kesimbangan dan keteraturan daya dalam jiwa sebagaimana uraian Ibn Miskawaih dalam kitab Tabdzib al-Akblaq wa Tathbir al-A'raq dengan anggapan bahwa manusia itu sejatinya dapat berada pada realitas kesempurnaan dan juga tingkat paling rendah. Apabila seseorang kuat kemampuan berpikirnya dan mampu mengendalikan daya bernafsu serta daya amarahnya, maka ia akan sampai kepada tingkat yang paling tertinggi. Begitu pula sebaliknya, apabila seseorang tersebut lemah daya berfikirnya, dan tidak mampu mengontrol daya bernafsu dan daya amarahnya, maka sejatinya ia berada di tingkat manusia yang paling rendah atau Ibn Miskawaih menyebutnya dengan seorang yang setara dengan binatang atau masih hidup dalam alam binatang. Ketiga, sebagai lanjutan dari tujuan-tujuan yang sebelumnya adalah untuk mengarahkan manusia menjadi manusia yang sempurna. (Al-Miskawaih, 2014). 
Kesempurnaan manusia menurut Ibn

Miskawaih ada dua macam sebagaimana unsur-unsur dimilikinya yaitu pada ranah kognitif dan unsur rohani dan ranah praktis atau unsur jasmani. Ranah kognitif, yaitu dengan bagian ini akan memunculkan pengetahuan. Terwujud apabila mendapatkan pengetahuan sedemikian rupa sehingga persepsinya, wawasannya dan kerangka berpikirnya akurat. Dengan demikian dia tidak akan melakukan kesalahan dalam keyakinannya dan tidak meragukan suatu kebenaran yang didapatkannya. Sedangkan ranah praktis, yaitu kesempurnaan karakter yang dimulai dari menertibkan daya-daya dan aktivitas yang khas bagi daya jiwa tersebut sehingga tidak saling berbenturan, namun hidup harmonis didalam dirinya sehingga lahirlah aktivitasnya sesuai dan tertata dengan baik diakhiri dengan penataan kehidupan sosial, dimana tindakan dikalangan masyarakat terjadi keselarasan dan masyarakat mencapai kebahagiaan seperti yang terjadi pada individu manusia.

Untuk mencapai beberapa tujuan ini, maka Ibn Miskawaih beranggapan perlunya sebuah pendidikan yang harus berdasarkan pemahaman tentang hakikat manusia, hal ini mengingat jiwa sebagai sumber prilaku. Oleh karena itu, menurut Ibn Miskawaih materi dalam pendidikan karakter harus ditekankan pada materi pembelajaran yang bermanfaat bagi terciptanya akhlak mulia dan menjadikan pedoman manusia agar sesuai dengan tujuannya. Dan dalam hal ini menurutnya, keberhasilan pendidikan karakter akan tercapai bila pendidik terlebih dahulu mengetahui tingkatan kesiapan peserta didik untuk menerima perbaikan karakter. Karena perlu diketahui bahwa, pada setiap manusia memiliki tingkatan yang berbeda-beda dalam menerima perbaikan karakter.

Secara ontologi pemikiran Ibn Miskawaih ini menjadi pembeda dengan pemikiran barat, yang lebih menekankan pada alam fisika saja. Dalam perspektif Miskawaih manusia juga bagian dari unsur metafisika yang memiliki hubungan dengan sang penciptanya. Hubungan inilah yang menuntut manusia untuk berkarakter yang baik sama halnya saat berhubungan dengan sang pencipta.

\section{Tinjauan Epistemologi}

Usaha-usaha yang diajukan oleh Ibn Miskawaih tentang perbaikan karakter dikenal juga dengan istilah metodologi pendidikan akhlak. Ada beberapa metode pembentukan karakter bagi diri yang diajukan Ibn Miskawsaih dalam hal ini.

Pertama, adanya kemauan yang sungguh-sungguh untuk berlatih terus menerus dan menahan diri (al-'adat wa al-jihad) untuk memperoleh keutamaan dan kesopanan yang sebenarnya sesuai dengan keutamaan jiwa. Metode ini termasuk metode yang paling efektif untuk memperoleh keutamaan jiwa. Latihan ini terutama diarahkan agar manusia tidak memperturutkan kemauan jiwa amarah dan jiwa bernafsunya. Karena kedua jiwa ini sangat terkait dengan alat tubuh, kata wujud latihan dan menahan diri dapat dilakukan antara lain dengan tidak makan ataupun minum yang membawa kerusakan tubuh tahu obat dengan lakukan puasa. Apabila kemalasan muncul, maka latihan yang patut 
dilakukan antara lain adalah bekerja yang ada unsur berat di dalamnya. Seperti mengerjakan salat yang lama, tahu melakukan sebagian pekerjaan baik yang di dalamnya ada unsur melelahkan. Latihan yang sungguh-sungguh semacam ini diumpamakan oleh Ibn Miskawaih seperti kesiapan Raja sebelum berhadapan dengan musuh. Kesiapan Yang dimaksud mengandung pengertian harus dilakukan secara dini, terus menerus, dan tidak menunggu waktu. Tampaknya oleh Ibn Miskawaih, metode semacam ini dinilai paling efektif untuk memperoleh keutamaan jiwa bernafsu jiwa amarah.

Kedua, yaitu dengan menjadikan semua pengetahuan dan pengalaman orang lain sebagai cermin bagi dirinya. Adapun pengetahuan dan pengalaman yang dimaksud dengan pernyataan ini adalah pengetahuan dan pengalaman berkenaan dengan hukumhukum akhlak yang berlaku bagi sebab munculnya kebaikan dan keburukan bagi manusia. Dengan cara ini seorang tidak akan hanyut ke dalam perbuatan yang tidak baik karena ia bercermin kepada perbuatan buruk dan akibatnya yang dialami orang lain. Manakala ia mengukur kejelekan atau keburukan orang lain, ia kemudian mencurigai dirinya bahwa dirinya juga sedikit banyak memiliki kekurangan seperti orang tersebut, lalu menyelidiki dirinya. Dengan demikian, maka setiap malam dan siang ia akan selalu meninjau kembali semua perbuatannya sehingga tidak satupun perbuatannya terhindar dari perhatiannya. Kejahatan atau kejelekan tidak pernah akan terlupakan dalam waktu yang lama. Selalu membekas dalam benak. Karena itu perbuatan yang sudah terlanjur jelek harus dihapus dengan perilaku yang baik secepatnya semua perbuatannya menjadi baik dan terhindar dari keburukan atau kejahatan.

Keberlanjutan dari metode sebelum ini adalah introspeksi atau mawas diri. Ini mengandung pengertian kesadaran seseorang untuk berusaha mencari cacat atau aib pribadi secara sungguh-sungguh. Untuk menjelaskan maksud metode ini, Ibn Miskawaih mengutip pendapat Galen yang setidaknya memiliki 3 langkah yang harus ditempuh. Pertama, berteman dengan orang tulus yang bersedia menunjukkan cacat jiwanya. Kedua, mengetahui pribadi melalui orang yang tidak menyenangi nya. Ketiga, bercermin terhadap perilaku orang lain. Ibn Miskawaih berpendapat bahwa langkah kedua lebih efektif dibanding langkah pertama. Beberapa alasan yang dimajukan oleh Ibn Miskawaih adalah sering tidak dijumpai kawan yang tulus yang bersedia menunjukkan berbagai kekurangan yang ada pada diri kita. Mayoritas kawan justru termasuk jenis pengambil muka. Secara diam-diam dia menyembunyikan berbagai kekurangan dan menyimpan rasa iri. Akan tetapi, musuh sering menunjukkan berbagai kekurangan tanpa ragu-ragu.

Ketiga,IbnMiskawaih mengemukakan pula penggunaan thariqun thab'iyyun (metode alamiah) dalam mendidik. Metode alamiah itu bertolak dari pengamatan terhadap potensipotensi insani. Mana yang muncul lahir lebih dahulu, maka pendidikan diarahkan kepada pemenuhan kebutuhan potensi yang lahir dahulu itu, kemudian kepada kebutuhan potensi berikutnya yang lahir sesuai dengan hukum alam. Potensi yang muncul pertama 
kali adalah gejala umum yang ada pada tingkat kehidupan hayawani dan nabati, kemudian terusmenerus lahir suatu gejala khusus yang berbeda dengan gejala potensi lainnya sampai menjadi tingkat kehidupan insani. Maka dari itu kata Miskawaih wajib bagi kita mulai dengan hasrat (kecenderungan) akan makan, yang muncul pada diri kita dengan jalan memenuhi kebutuhan kecenderungan, lalu muncul kecenderungan ghadabiyyah dan cinta kemuliaan, kita didik dengan jalan memenuhi kecenderungan, kemudian terakhir lahir kecenderungan kepada ilmu pengetahuan (dari jiwa berpikir) maka kita didik dengan jalan memenuhi kecenderungan itu.

Urutan kemunculan inilah yang dimaksudkan oleh Ibn Miskawaih sebagai metode thabi'i (alami), karena didasarkan proses kejadian manusia, yakni pertama kali embrio lalu bayi kemudian orang dewasa. Potensi-potensi ini lahir berurutan secara alamiah. Ide pokok dari thariqun thabi'iyyun dari Miskawaih adalah bahwa pelaksanaan kerja mendidik itu hendaknya didasarkan atas perkembangan lahir batin manusia. Setiap tahap perkembangan manusia mempunyai kebutuhan psycho-phisiologis dan cara mendidik hendaklah memperhatikan kebutuhan ini sesuai dengan tahap perkembangannya. (Hariyanto \& Anjaryati, 2016).

Kemudian yang keempat, metode oposisi. Ada 2 langkah yang perlu dilakukan untuk metode ini. Seperti halnya penyakit jasmani terhadap penyakit jiwa juga dilakukan dengan: pertama, mengetahui jenis penyakit dan sebabnya, dan kedua mengobati atau menghapus penyakit tersebut dengan menghadirkan lawan-lawannya. Penyebab akhlak yang buruk harus dilawan dengan ilmu dan amal. Keburukan dengan ilmu disebut sebagai pengobatan teoretis, pengobatan dengan amal disebut pengobatan praktis. Pengobatan teoritis mempunyai efek untuk menimbulkan keinginan melawan penyebab penyakit dengan langkah-langkah amal.

Dengan demikian, ilmu menempati posisi awal dibanding amal. Amal itu sendiri juga harus berlawanan dengan perbuatan yang timbul dari sifat-sifat buruk. Karena ilmu tidak pernah akan mengalami. akhir, oleh karena hal ini pula nampaknya Ibn Miskawaih sangat menekankan di bidang ini. Lebih jauh lagi dapat dipahami bahwa Ibn Miskawaih menganggap ilmu saja Sebenarnya cukup untuk menghapus penyakit jiwa. Atau dapat pula dipahami bahwa dengan adanya pengetahuan terhadap penyakit jiwa, manusia terdorong untuk berbuat melawan penyakit tersebut. (Maghfiroh, 2017).

\section{Tinjauan Aksiologi}

Ketika ingin berbicara tentang nilai pendidikan karakter sebagaimana dimaksudkan oleh Ibn Miskawaih, maka pembahasannya akan sangat berkaitan dengan teori dasar yang digunakannya dalam hal keutamaan karakter. Teori dasar yang dikembangkan oleh Ibn Miskawaih dalam hal ini adalah jalan tengah atau "pertengahan" (al-awsath atau al-wasath). (Ali \& Syaifuddin, 2020).

Jalan tengah ini dirujuk kepada makna "posisi tengah-tengah" yang mewujud dalam keseimbangan, moderat, harmoni, utama, mulia, bahkan posisi tengah-tengah di antara dua sisi yang saling bertentangan. Ibn Miskawaih menggunakan istilah jalan tengah ini dalam artian untuk capaian aktivitas daya- 
daya dalam jiwa manusia sebagaimana telah dijelaskan, yang kemudian menjadi patokan kesempurnaan manusia. Dengan penjelasan, apabila aktivitas jiwa rasional memadai dan tidak keluar dari jalur diirnya dan ketika jiwa ini mencari pengetahuan yang benar bukan yang diduga sebagai pengetahuan tetapi sebenarnya kebdodohan, maka jiwa ini akan mencapai al-hikmah (kebijaksanaan). Apabila aktivitas jiwa kebinatangan memadai, dan terkendali oleh jiwa berfikir dan tidak menentang jiwa berfikir dan juga tidak tenggelam dalam keinginnanya jiwa itu sendiri maka jiwa ini akan mencapai sikap kesederhanaan al-iffah (menjaga kesucian diri/kesederhanaan). Kemudian apabila jiwa amarah memadai, mematuhi segala aturan yang ditetapkan oleh jiwa berfikir dan ia tidak bangkit pada waktu yang tidak tepat atau tidak terlalu bergejolak maka jiwa ini akan mencapai sikap al-saja'ab (keberanian). Barulah kemudian timbul dari ketiga capaian ini yang merupakan penyempurna adalah sikap al-adalah (keadilan). (Al-Miskawaih, 2014)

Keempat keutamaan ini merupakan pokoknya, sementara keumataan-keutamaan yang lain merupakan cabangnya yang sedemikian banyak dan tidak terhitung jumlahnya. Keutamaan yang di jadikan patokan oleh Ibn Miskawaih ini apabila ditelaah dan dikaji pendapat-pendapat cendikiawan muslim yang lain maka akan didapati kesamaan-kesamaan seperti halnya al-Ghazali yang menjadikan keutamaan tersebut juga sebagai patokan dalam konsep pendidikan akhlaknya. (Kurniawan, 2017). Begitu pula Ibn Miskawaih seperti yang dimaksud, ia memberikan sikap tengah atau jalan tengah ini sebagai acuan dalam hal pendidikan karakter. Karena sebenarnya posisi jalan tengah ini menjadi arah ataupun haluan untuk manusia berprilaku. (Mahmud, 2020).

\section{SIMPULAN}

Berdasarkan uraian hasil dan pembahasan penelitian di atas maka dapat disimpulkan bahwa secara ontologi, pendidikan karakter Ibn Miskawaih adalah suatu upaya baik itu berupa nasihat, bimbingan, ataupun pembelajaran yang secara hakikat bertujuan untuk menertibkan ketiga daya yang ada pada jiwa manusia (alnathiqah, al-ghadabiyah, dan asy-syahwiyyah) yang mana daripadanya prilaku manusia berasal. Dimana dengan tertibnya ketiga daya ini, maka prilaku manusia akan senantiasa baik dan sifatnya spontanitas atau tanpa perlu pertimbangan terlebih dahulu. Kemudian secara epistemologi, metodologi pendidikan karakter tersebut meliputi kemauan yang sungguh-sungguh serta diiringi menahan diri, kemudian pengetahuan tentang baikburuknya prilaku dan pengalaman orang lain sebagai cerminan diri agar senantiasa melakukan introspeksi, thariqun thabiiyyah (metode alamiah) dalam mendidik diri yakni pendidikan yang disesuaikan dengan urutan munculnya daya-daya yang ada pada jiwa, dan yang terakhir adalah metode oposisi atau pemahaman tentang penyakit-penyakit jiwa yang menyebabkan buruknya prilaku dengan menghindari penyakit-penyakit tersebut atau menghadirkan lawan-lawan daripada penyakit tersebut. Terakhir adalah secara aksiologi yang mana pendidikan karakter Ibn Miskawaih adalah bermuara kepada 
wasathiyyah (jalan tengah) dengan pokok keutamaan seperti al-hikmah (kebijaksanaan atau kearifan), al-iffah (kesederhanaan atau menjaga kesucian diri), al-saja'ah (keberanian) dan al-'adalah (keadilan).

\section{DAFTAR PUSTAKA}

Abong, R. (2015). Konstelasi Kurikulum Pendidikan di Indonesia. Jurnal AtTurats, 9(2), 37-47. https://doi. org/10.24260/at-turats.v9i2.314

Adib, H. M. (2013). Filsafat Ilmu: Ontologi, Epistemol ogi, Aksiologi, dan Logika Ilmu Pengetahuan. Prosiding Seminar Nasional Bahasa dan Sastra. http:/ / www. openjournal.unpam.ac.id/index.php/ Proceedings/article/view/4056

Agung. (2018). Konsep Pendidikan Karakter Islami; Kajian Epistemologis. AlTarbawi Al-Haditsab: Jurnal Pendidikan Islam, 3(2), 76-90. https://doi. org/10.24235/tarbawi.v3i2.3315

Al-Miskawaih, A. A. A. (2014). Tabdrib AlAkblaq, Terj. Helmi Hidayat (8th ed.). Mizan.

Ali, M., \& Syaifuddin, M. (2020). Ketokohan Ibn Miskawaih dalam Bidang Pendidikan Karakter. Jurnal Progress: Wahana Kreativitas dan Intelektualitas, 8(2), 300. http://dx.doi.org/10.31942/ pgrs.v8i2.3961

Arifin, Z. (2011). Pendidikan Moral dalam Multi Perspektif. Sosial Budaya, 8(1), 132-151. http://dx.doi.org/10.24014/ sb.v8i1.353

Bakri, S. (2017). Antropologi Metafisika Ibn Miskawaih. In IAIN Surakarta. LP2M IAIN Surakarta. http://eprints.iainsurakarta.ac.id

Bakri, S. (2018). Pemikiran Filsafat Manusia Ibnu Miskawaih: Telaah Kritis Atas Kitab Tahdzib Alakhlaq. Al-A'raf: Jurnal Pemikiran Islam Dan Filsafat, 15(1), 147166. https://doi.org/10.22515/ajpif. v15i1.1102

Chatterjee, A. (2011). Ontology, Epistemology, and Multimethod Research in Political Science. Philosophy of the SocialSciences,43(1),73-99. https:// doi.org/10.1177/0048393111415380

Hamim, N. (2017). Pendidikan Akhlak: Komparasi Konsep Pendidikan Ibnu Miskawaih dan al-Ghazali. Ulumuna, 18(1), 21-40. https://doi. org/10.20414/ujis.v18i1.151

Hariyanto, H., \& Anjaryati, F. (2016). Character Building: Telaah Pemikiran Ibnu Miskawaih tentang Pendidikan Karakter. Jurnal Pendidikan Islam Indonesia, 1(1), 111-118. https://doi. org/10.35316/jpii.v1i1.41

Hayden, M. J. (2012). What Do Philosophers of Education Do? An Empirical Study of Philosophy of Education Journals. Studies in Philosophy and Education, 31(1), 1-27. https://doi.org/10.1007/ s11217-011-9262-7

Khojir, K. (2011). Membangun Paradigma Ilmu Pendidikan Islam: Kajian Ontologi, Epistemologi dan Aksiologi. Dinamika Ilmu, 11(1), 60-73. https:// doi.org/10.21093/di.v11i1.51

KPAI. (2020). Sejumlah Kasus Bullying Sudah Warnai Catatan Masalah Anak di Awal 2020, Begini Kata Komisioner KPAI. Komisi Perlindungan Anak Indonesia. https://jabar.tribunnews.com

Kurnia, R., \& Sulfia, M. (2018). Konsep Pendidikan Karakter dalam Perspektif Pemikiran Zakiah Daradjat. Fitra, 3(2). http://jurnal.staitapaktuan.ac.id/ index.php/fitra/article/view/48

Kurniawan, S. (2017). Pendidikan Karakter dalam Islam Pemikiran Al-Ghazali tentang Pendidikan Karakter Anak Berbasis Akhlaq al-Karimah. Tadrib, 3(2), 197-216. https://doi. org/10.19109/Tadrib.v3i2.1792 
Lestari, A. (2017). Konsep Guru dan Anak Didik dalam Pendidikan Akhlak Menurut Ibnu Maskawaih. Tarbawi: Jurnal Pendidikan Islam, 14(2), 125-134. https://doi.org/10.34001/tarbawi. v14i2.618

Listyanti, R. (2019). KPAI: 24 Kasus Anak di Sekolah pada Awal 2019 Didominasi Kekerasan. Komisi Perlindungan Anak Indonesia (KPAI). https://tirto.id/ kpai

Lubis, M. (2019). Konsep Pendidikan Karakter dalam Perspektif Islam dan Barat (Studi Komparatif Pemikiran Nashih Ulwan dan Thomas Lickona). Al-Fikru, 12(2), 55-65. http://alfikru. staiserdanglubukpakam.ac.id/index. $\mathrm{php} /$ index

Ludwig, D. (2016). Overlapping ontologies and Indigenous knowledge. From integration to ontological selfdetermination. Studies in History and Philosophy of Science Part A, 59(5), 36-45. https://doi.org/https://doi. org/10.1016/j.shpsa.2016.06.002

Maghfiroh, M. (2017). Pendidikan Akhlak Menurut Kitab Tahzib Al-Akhlaq Karya Ibnu Miskawaih. Tadris: Jurnal Pendidikan Islam, 11(2), 206-218. http://dx.doi.org/10.19105/tjpi. v11i2.1169

Mahmud, A. (2020). Akhlak Islam Menurut Ibnu Miskawaih. Aqidah: Jurnal Ilmu Aqidah, 6(1), 84-98. https://doi. org/10.24252/aqidahta.v6i1.15566

Moloeng, L. J. (2018). Metodologi Penelitian Kualitatif Remaja Rosdakarya. Inter Komunika, Stikom InterStudi.

Mu'in, F. (2016). Pendidikan Karakter: Konstruksi Teoritik dan Praktik (5th ed.). Ar-Ruzz Media.

Mubin, M. S. (2020). Pendidikan Karakter Menurut Ibnu Miskawaih dan Implementasinya Terhadap Pembelajaran Masa Pandemi. Jurnal
Reforma, 9(2), 114-130.

Mudlofir, A. (2016). Pendidikan Karakter: Konsep dan Aktualisasinya dalam Sistem Pendidikan Islam. Nadwa, 7(2), 229-246. http://dx.doi.org/10.21580/ nw.2013.7.2.560

Mulia, H. R. (2019). Pendidikan Karakter: Analisis Pemikiran Ibnu Miskawaih. Tarbawi: Jurnal Ilmu Pendidikan, 15(1), 39-51. https://doi.org/10.32939/ tarbawi.v15i1.341

Nalva, M. F. (2020). Pendidikan Karakter Perspektif Ibnu Miskawaih. Jurnal PAI Raden Fatah, 2(1), 11-27. http://jurnal. radenfatah.ac.id/index.php/pairf/ article/view/4419

Noor, M. (2018). Pendidikan Karakter: Merawat Nurani Kebangsaan. Mimbar Administrasi, 14(1), 18-31. http:// jurnal.untagsmg.ac.id/index.php/mia/ article/view/904

Nuriman, N., \& Emzir, E. (2018). The Personality of Main Character in The Film Series Nobuta Wo Produce By Izumi KizarA (a Carl Gustav Jungâ Psychoanalytic Approach). IJLECR -International Journal of Language Education and Culture Review, 4(1 SEArticles). https://doi.org/10.21009/ IJLECR.041.06

Nurkhalisyah, Mansur, R., \& Syafi'i, I. (2020). Pendidikan Karakter Dalam Perspektif Pendidikan Islam (Relevansi Pemikiran Ki Hajar Dewantara dan Ibnu Miskawaih). Vicratina: Jurnal Pendidikan Islam, 5(8), 93-99. http:// riset.unisma.ac.id/index.php/fai/ article/view/7643

Prasetiya, B. (2018). Dialektika Pendidikan Akhlak dalam Pandangan Ibnu Miskawaih dan Al-Gazali. Intiqad: Jurnal Agama Dan Pendidikan Islam, 10(2), 249-267. https://doi.org/10.30596/ intiqad.v10i2.2381

Purnamansyah, P. (2014). Pendidikan Karakter 
dalam Pandangan Pendidikan Islam

(Studi Kasus: Pemikiran Doni Koesoema Albertus) [Universitas Muhammadiyah Surakarta]. http://eprints.ums. ac.id/29065/

Rahayu, F. (2019). Pendidikan Karakter Analisis Pemikiran Ibnu Miskawaih. Al-Mudarris Jurnal Ilmiah Pendidikan Islam), 2(1), 19-38. https://doi. org/10.23971/mdr.v2i1.1402

Rawnsley, M. M. (1998). Ontology, Epistemology, and Methodology: A Clarification. Nursing Science Quarterly, 11(1), 2-4. https://doi. org/10.1177/089431849801100102

Rifai, A. (2016). Pendidikan Karakter dan Pendidikan Akhlak. Al Qalam: Jurnal Ilmiah Keagamaan Dan Kemasyarakatan, 9(1), 97-116. http://dx.doi. org/10.35931/aq.v0i0.55

Safri, Z. (2017). Tinjauan Filsafat Pendidikan Ibn Miskawaih Terhadap Fenomena Kenakalan Remaja. Kelola: Journal of Islamic Education Management, 2(1), 102 116. https://doi.org/10.24256/kelola. v2i1.447

Subekti, T., \& Sumarlam, S. (2017). Nilai Karakter Kebangsaan dalam Buku Teks Bahasa Indonesia Sekolah Dasar. Edukasi, 9(1), 71-81. https://doi. org/10.31603/edukasi

Thomson, A. (1964). The Philosophy of J. F. Ferrier. Philosophy, 39(147), 46-62. http://www.jstor.org/stable/3749133

Zaimudin, Z. (2018). Memaknai pendidikan Karekter dalam Pemikiran Ibn Miskawaih. Jurnal Qiroah, 8(1), 63-95. https://doi.org/10.33511/qiroah. v1i1.54 